\title{
p53, Apaf-1, caspase-3, and -9 are dispensable for Cdk5 activation during cell death
}

\author{
$L \operatorname{Lin}^{1,2}, Y Y e^{1}$ and $Z$ Zakeri ${ }^{\star, 1}$ \\ ${ }^{1}$ Department of Biology, Queens College and Graduate Center of the City \\ University of New York, 65-30 Kissena Blvd, Flushing, NY 11367, USA \\ 2 Current address: Department of Dermatology, Columbia University, College of \\ Physicians and Surgeons, New York, NY 10032, USA \\ * Corresponding author: Z Zakeri, Department of Biology, Queens College and \\ Graduate Center of CUNY, 65-30 Kissena Blvd, Flushing, NY 11367, USA. Tel: \\ +1 118997 3417; Fax: + 1718997 3429; E-mail: Zahra_zakeri@qc.edu
}

Received 23.9.04; revised 24.5.05; accepted 30.5.05; published online 15.7.05 Edited by M Piacentini

\begin{abstract}
Cyclin-dependent kinase 5 (Cdk5) is a member of the cyclindependent kinase family that is mostly seen in neurons, does not vary with cell cycle, and is activated in many neurodegenerative disorders and other non-neuronal pathologies, but its relationship to non-neuronal apoptosis is not understood, nor is the control of the activation of Cdk5 by its activators. The most widely studied activator of Cdk5, p35, is cleaved to p25 by calpain, an event that has been linked with activation of Cdk5 and neuronal death. Here we report that calpain-mediated Cdk5/p25 activation accompanies nonneuronal as well as neuronal cell death, suggesting that the p35/calpain/p25/Cdk5 activation sequence is a general feature of cell death. We further demonstrate that Cdk5 can be activated in the absence of p53, Apaf-1, caspase-9, and -3 during cell death, indicating that its activation relates more to cell death than to a specific pathway of apoptosis.

Cell Death and Differentiation (2006) 13, 141-150.

doi:10.1038/sj.cdd.4401717; published online 15 July 2005
\end{abstract}

Keywords: Cdk5; apoptosis; p53; Apaf-1; caspase-3 and -9

Abbreviations: Cdk, cyclin-dependent kinase; Cdk5, cyclindependent kinase 5; CHX, cycloheximide; $\mathrm{CPT}$, camptothecin; $\mathrm{CS}$, calpastatin; EtOH, ethanol; PARP, poly (ADP ribose) polymerase; PD, PD150606; SBDPs, spectrin breakdown products; TUNEL, terminal deoxynucleotidyl transferase-mediated dUTP nick end labeling

\section{Introduction}

Here we document that activation of cyclin-dependent kinase 5 (Cdk5) occurs during cell death in mesodermal cells in the same situations as has been reported for neurons and other cells, thus demonstrating that activation of Cdk5 occurs generally in most or all dying cells. We then address the mechanism of its activation during cell death.

Cdk5 is a member of the cyclin-dependent kinase (Cdk) family originally identified from bovine brain by its sequence homology to human Cdc2. ${ }^{1}$ Cdk5 is expressed at both mRNA and protein levels in a broad spectrum of tissues and cell lines, with the highest levels detected in neurons. ${ }^{2-6}$ Unlike other cell cycle-promoting members of Cdk family, Cdk5 kinase primarily modulates neuroskeletal dynamics in postmitotic neurons. ${ }^{3,7,8}$ Cdk5 plays an essential role in both developing and adult neurons, including neuronal migration, ${ }^{9,10}$ axon guidance ${ }^{11}$ neurite outgrowth, ${ }^{7}$ dynamics of synaptic structure, ${ }^{12-14}$ neurotransmission, ${ }^{15,16}$ and neuronal secretion. ${ }^{17}$ Cdk5 null mice suffer perinatal mortality, with severe defects in neuronal migration and laminar configuration in the cerebral cortex. ${ }^{18}$ However, Cdk5 is not restricted to neurons. It is also prominent in the testis, where its level is high but its function is unknown (our unpublished data), developing muscle, ${ }^{19,20}$ bFGF-stimulated bovine aortic endothelial cell proliferation, ${ }^{21}$ and differentiating monocytes. ${ }^{22,23}$

Cdk5 is activated in dying cells, including both developing tissues (interdigital areas of mouse limbs, ${ }^{24}$ differentiating rat lens, ${ }^{4}$ and mouse brain ${ }^{5}$ ) and adult tissues (regressing mouse prostate following androgen withdrawal and atrophic mouse ovaries $\left.^{5}\right)$. The association between Cdk5 activation and cell death is seen in pathology: rat lungs infected with Streptococcus pneumoniae,${ }^{25}$ mouse limbs infected with Leishmania major, ${ }^{26}$ preterm lamb lungs after ventilation, ${ }^{27}$ cyclophosphamide-treated mouse embryos, ${ }^{28}$ and several neurodisorders and neuronal injuries. ${ }^{29-37}$ The regulatory signals and mechanisms by which Cdk5 is activated remain undefined.

As with other Cdks, Cdk5 is activated by association with an activator. p35 is the most important regulatory subunit of Cdk5 during neurodevelopment, ${ }^{38-40}$ and we confirmed that it interacts with Cdk5 during cell death. ${ }^{28}$ Cleavage of p35 to p25 by calpain has been linked to activation of Cdk5. Inhibition of calpain activation, which blocks p25 production and Cdk5 activation, prevents neuronal cell death..$^{29,31,32,35,41,42}$ Here we document the generation of p25 during cell death, as we had previously suggested. ${ }^{28}$ We also establish that calpainmediated Cdk5/p25 activation coincides with cell death in both non-neuronal and neuronal systems, suggesting the generality of the role of Cdk5 in cell death.

The signals that activate calpain and Cdk5 are unclear, as is the question of how activation of Cdk5 relates to cell death. To address this latter issue, we investigate the relationship of Cdk5 to major cell death pathways. We first examine the relationship of Cdk5 to the p53-mediated signaling pathway. ${ }^{43-45}$ p53 may mediate mitochondrial cell death signaling through the elevation of the level of reactive oxygen species, ${ }^{46}$ while oxidative stress can stimulate Cdk5 activity by inducing an upregulation of p35 in human neuroblastoma IMR-32 cells. ${ }^{47}$ Reactive oxygen species (ROS) are instrumental in a number of neurodegenerative disorders where Cdk5 is activated. ${ }^{48,49}$ Furthermore, in vitro p53 is a substrate of Cdk5. ${ }^{50}$ We therefore investigate crosstalk between p53 and Cdk5.

Activation of the apoptosome and the subsequent activation of caspase- 9 and -3 follow mitochondrial dysfunction ${ }^{51}$ in 
the intrinsic pathway. We therefore also ask how Cdk5 interacts with these caspases. Finally, we demonstrate that Cdk5 can be activated during cell death in the absence of $p 53$, Apaf-1, caspase-9, and -3 .

Nevertheless, activation of Cdk5 is a consistent feature of many or most deaths of ectodermal and mesodermal cells. Since Cdk5 activation is coincident but independent of these pathways, the mechanism by which it is activated and the function of its activation remain to be elucidated.

\section{Results}

\section{Apoptotic cell death is induced by different stimuli in $\mathbf{C 8}$ and $\mathbf{A 9}$ cells}

To examine the involvement of p53 in the activation of Cdk5, we used C8 and A9 cells, which are mouse embryonic fibroblast cells oncogenically transformed with both $E 1 A$ and ras, and containing wild-type p53 or p53-/-, respectively. ${ }^{43}$ Toxins such as ethanol (EtOH), cycloheximide (CHX), and camptothecin (CPT) kill these cells. EtOH at high concentrations damages the cell membrane. ${ }^{52} \mathrm{CHX}$ inhibits protein synthesis and is otherwise toxic at the pharmacological levels normally used to induce apoptosis. ${ }^{53}$ CPT inhibits DNA topoisomerase I. ${ }^{54}$ All lead to apoptosis in a variety of cells. ${ }^{55-58}$

Death induced in $\mathrm{C} 8$ and $\mathrm{A} 9$ cells after exposure to $\mathrm{EtOH}$ (2.5\%), CHX $(25 \mu \mathrm{g} / \mathrm{ml})$, or CPT $(20 \mu \mathrm{M})$ for $18 \mathrm{~h}$ was determined by trypan blue (TB) exclusion assay. Owing to their sensitivity to low serum (1\% FBS), untreated control C8 cells manifested of the order of $15 \%$ cell death (Figure 1A). All three toxins induced substantial cell death in C8 - up to 77, 90, and $100 \%$, respectively (Figure $1 \mathrm{~A}$ ). In p53-/- A9 cells, after $18 \mathrm{~h} \mathrm{CHX}$ and CPT induced 75 and $58 \%$ cell death, respectively (Figure $1 \mathrm{~A}$ ), indicating that these compounds could induce p53-independent cell death. EtOH, however, caused $77 \%$ cell death in C8 cells, but only $18 \%$ cell death in A9 cells (Figure 1A), indicating that $\mathrm{EtOH}$ induced p53dependent death in $\mathrm{C} 8$.

$\mathrm{EtOH}, \mathrm{CHX}$, and CPT can induce apoptosis or necrosis, depending on cell line or conditions. ${ }^{54,59,60}$ To evaluate the cell death induced under our conditions, we employed several markers to characterize apoptotic cell death, including examination of DNA fragmentation both by gel electrophoresis and in situ detection of fragmented DNA by terminal deoxynucleotidyl transferase-mediated dUTP nick end labeling (TUNEL), measurement of nuclear fragmentation by Hoechst staining, and activation of caspase- 3 and cleavage of poly (ADP ribose) polymerase (PARP).

As shown in Figure $1 \mathrm{~B}$, in $\mathrm{C} 8$, all three chemicals induced DNA ladders above background, indicating fragmented chromatin and internucleosomal DNA fragmentation. $\mathrm{CHX}$ and CPT-treated A9 cells also showed typical DNA ladders, but ladders were barely detectable in $\mathrm{EtOH}$-treated cells, correlating with the low cell death. Control A9 cells were negative. In C8, DNA fragmentation was further confirmed by TUNEL, and nuclear fragmentation and condensation were detected by Hoechst staining in all treated samples, as exemplified in Figure 1C. CHX- and CPT-treated A9 cells


D
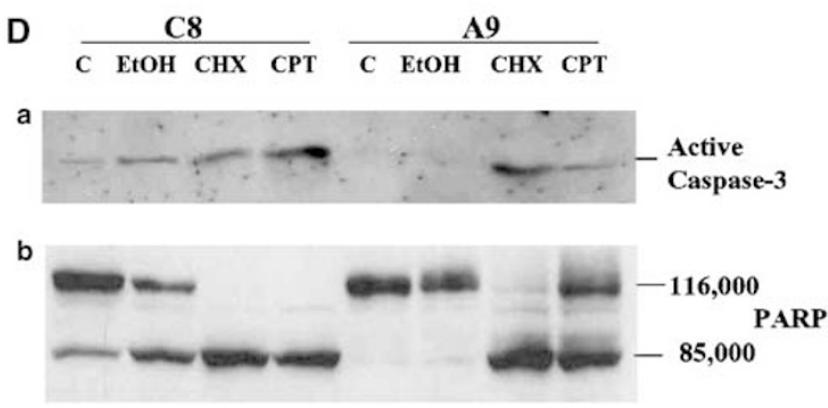

Figure 1 Different toxicants induce apoptosis in $\mathrm{C} 8$ and A9 cells. Equal numbers $\left(5 \times 10^{6} / 100 \mathrm{~mm}\right.$ plate $)$ of cells were seeded in growth media and switched to media supplemented with $1 \%$ FBS for treatment. Cells were untreated as control (Control or $\mathrm{C}$ ) or incubated with toxicants, including $\mathrm{EtOH}$ $(2.5 \%), \mathrm{CHX}(25 \mu \mathrm{g} / \mathrm{ml})$, and CPT $(20 \mu \mathrm{M})$, for $18 \mathrm{~h}$. (A) Levels of cell death induced in $\mathrm{C} 8$ and $\mathrm{A} 9$ were determined by trypan blue exclusion. (B) DNA ladder was examined on a $2 \%$ agarose gel. (C) Untreated and CPT-treated C8 cells were fixed with $3 \%$ paraformaldehyde, and DNA fragmentation was determined by TUNEL assay (upper panels). C, TUNEL control, no signal; CPT, TUNELpositive signal is the brown dark staining in dying/dead cells as indicated by arrows. Nuclear morphology was examined using Hoechst fluorescent dye (lower panels). Arrow indicates fragmented nuclei. (D) Cells were lysed with RIPA buffer, and equal amounts of lysates were resolved by SDS-gel electrophoresis, followed by immunoblotting with active caspase-3 antibody (a) or PARP antibody (b), as described in Materials and Methods

were also TUNEL positive and showed nuclear fragmentation (data not shown).

Activation of caspase- 3 was demonstrated by Western blot (WB) using an antibody that detects active $17 \mathrm{kDa}$ caspase-3. In $\mathrm{C} 8$ cells treated with $\mathrm{EtOH}, \mathrm{CHX}$, or CPT for $18 \mathrm{~h}$, caspase3 was active (Figure 1D, a), and its activation corresponded to the level of cell death (Figure 1A). Activation was further confirmed by PARP cleavage by WB. When C8 cells were exposed to the three toxins, the $85 \mathrm{kDa}$ band corresponding to caspase-3-specific PARP cleavage was substantially above the basal level corresponding to the $15 \%$ background cell 
death shown in Figure 1A (Figure 1D, $a$ and $b$ ). In A9 cells, as in $C 8$ cells, we found caspase-3 activation (Figure 1D, a) and PARP cleavage (Figure 1D, b) during cell death by CPT and $\mathrm{CHX}$. However, in EtOH-treated A9 cells, there was neither caspase-3 activation nor PARP cleavage (Figure 1D, $a$ and b). Thus, the death of $\mathrm{C} 8$ cells induced by $\mathrm{EtOH}, \mathrm{CHX}$, or CPT was apoptotic. $\mathrm{CHX}$ and $\mathrm{CPT}$ can induce apoptotic cell death independent of p53 in A9, while induction of cell death by EtOH depends on p53.

We further evaluated the kinetics of CPT-induced cell death, activation of caspase-3, and activation of Cdk5 in C8 and $A 9$. By $6 \mathrm{~h}, \mathrm{C} 8$ cell death was statistically greater than that in $A 9$ (49\% positive $C 8$ cells by TB, compared with $4 \%$ in $A 9$; Figure $2 \mathrm{~A}$ ) and continued in this trajectory for the next $2 \mathrm{~h}$. However, by $12 \mathrm{~h}$, A9 cells started to die $(20 \%)$, increasing to $40 \%$ by $15 \mathrm{~h}$ (Figure $2 \mathrm{~A}$ ). Activation of caspase- 3 started at $6 \mathrm{~h}$ in $\mathrm{C} 8$ (Figure 2B, a), correlating with strong induction of p25, indicative of $\mathrm{Cdk} 5$ activation (Figure $2 \mathrm{~B}, \mathrm{~b}$ ). Induction of p25 is a reliable indicator and measure of Cdk5 activation. ${ }^{28,29,31}$ In

A

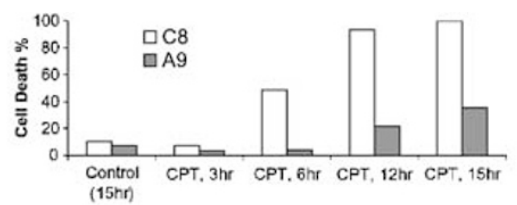

B
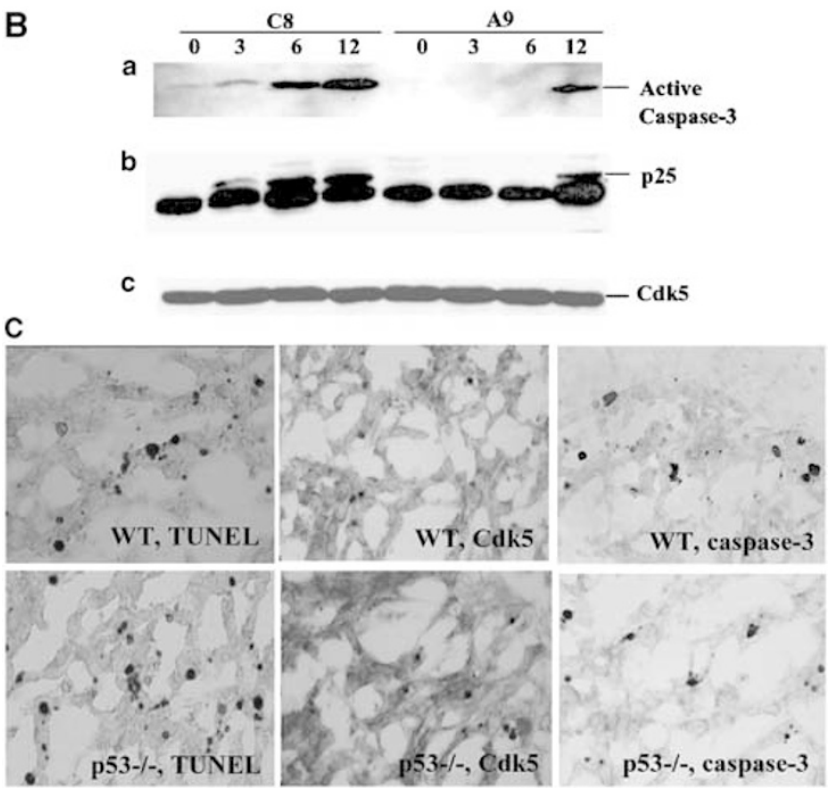

Figure 2 Lack of p53 causes a delayed induction of cell death and activation of Cdk5, but does not affect cell death or Cdk5 protein expression in developing mouse embryos. (A) There is a delayed induction of cell death in p53-deficient A9 cells. $\mathrm{C} 8$ and $\mathrm{A} 9$ cells were exposed to CPT, and cell death was determined by trypan blue exclusion. Averages of four independent experiments are shown with S.D. less than 5\%. (B) Immunoblots of protein lysates from C8 and A9 probed with antibody against active caspase-3 (a), p35 (b), or Cdk5 (c) cells indicate a delayed but eventual clear activation of Cdk5 and caspase-3 in CPTinduced cell death in A9 cells. (C) Both p53 wild-type and mutant mouse embryos (ED 13.5) were fixed and sectioned as described in Materials and Methods. TUNEL assay and immunohistochemistry study were performed on near-serial sections for comparison. There is no difference in the level or pattern of cell death and Cdk5 protein expression between the brains of wild-type and p53-/embryos. Caspase-3 activation further indicates a caspase-3-involved cell death in this region. Magnification, $\times 40$
$\mathrm{A}$, it took $12 \mathrm{~h}$ to activate caspase-3 (Figure 2B, a) and induce p25 (Cdk5 activation - Figure 2B, b). As expected, the level of Cdk5 protein was constant for the $18 \mathrm{~h}$ in both $\mathrm{C} 8$ and A9 (Figure 2B, c, data for 8,15 , and $18 \mathrm{~h}$ not shown). Thus, although p53 was not required for p53-independent apoptosis, such as CHX- and CPT-induced cell death, lack of p53 resulted in a delay of both apoptosis and Cdk5 activation. Cdk5 activation correlates with apoptosis, but not p53.

The influence of p53 on the activation of Cdk5 was further examined in p53 knockout mouse embryos. Developing mouse embryos manifest apoptotic cell death in many organs. We first examined apoptotic cell death by TUNEL in developing p53-/- mouse embryos at ED13.5, 14.5, and 15.5 (data for 14.5 and 15.5 not shown). TUNEL assay on sections of wild-type and p53-/- embryos indicated substantial levels of cell death in the trigeminal region of both embryos (Figure $2 \mathrm{C}$ ); this death was therefore p53-independent. On an adjacent serial slide, the strong caspase-3 immunoreactivity indicated activation of caspase-3 in both wild-type and p53-/- embryos (Figure 2C). Similarly, Cdk5 immunoreactivity, indicative of its activation, ${ }^{28}$ was detected in both wild-type and p53 knockout mouse embryos. We found no difference in the level of cell death or activation of Cdk5 between wild-type and p53-/- (Figure 2C), again correlating Cdk5 with cell death, but not p53.

\section{Cdk5 is activated in the absence of functional apoptosome (Apaf-1) and subsequent caspase-9 activation}

To address whether an intact intrinsic cell death pathway is required for Cdk5 activation, we first examined Apaf-1. We used Apaf-1 null mouse embryos at stages ED12.5, 13.5, and 15.5. In all the three stages in both wild-type and null mice, cell death correlated with Cdk5 expression. In ED13.5 Apaf-1 knockout mouse embryos, many cells in the periphery of the liver were positive for both DNA fragmentation and Cdk5 (Figure 3A, a, black arrows). Therefore, Apaf- 1 is not required for Cdk5 activation during cell death.

As confirmation, primary mouse embryonic fibroblasts lacking Apaf-1 as well as their wild-type counterparts were exposed to $\mathrm{CHX}(25 \mu \mathrm{g} / \mathrm{ml})$ or CPT $(20 \mu \mathrm{M})$. Cells began to show apoptotic morphology at $36 \mathrm{~h}$. By this time, $40 \%$ of $\mathrm{CHX}$ exposed Apaf- $1+/+$ and $17 \%$ of Apaf-1- $1-$ cells were TBpositive, while $45 \%$ of CPT-exposed Apaf-1+/+ and only $20 \%$ of Apaf-1-/- cells were dead (Figure 3A, b). Apaf-1deficient cells are more resistant to cell death, in accordance with the argument that Apaf-1 is apoptogenic.

Cdk5 protein did not change (Figure 3A, c). However, Cdk5 was activated, as indicated by generation of p25 in all dying cells (Figure 3A, d). Thus, again, Cdk5 activation correlates with cell death. In these experiments, activation can occur in the absence of Apaf-1.

Caspase-9 is the direct downstream target of the apoptosome. We therefore investigated the relationship between caspase-9 and Cdk5 activation. Both caspase-9-/- primary mouse embryonic fibroblast cells and their counterparts were exposed to $\mathrm{CHX}(25 \mu \mathrm{g} / \mathrm{ml})$ or CPT $(20 \mu \mathrm{M})$ and cell death was determined by TB. At $24 \mathrm{~h}$ after exposure, $\mathrm{CHX}$ induced 88 

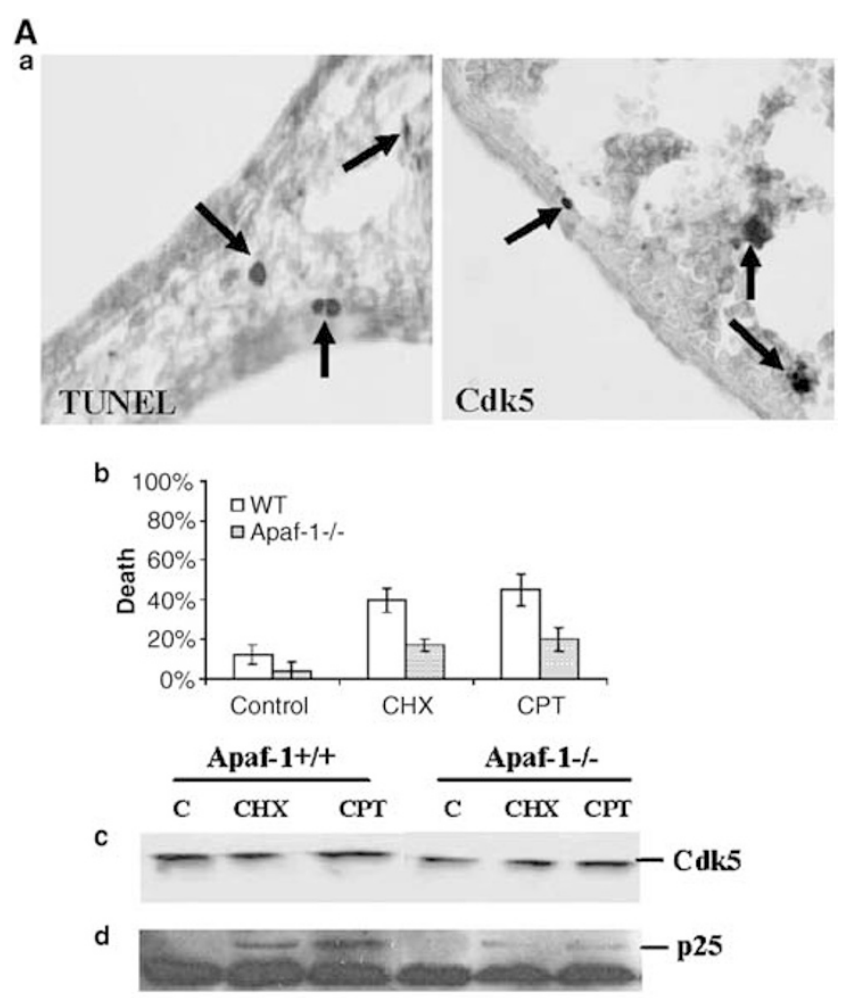

B
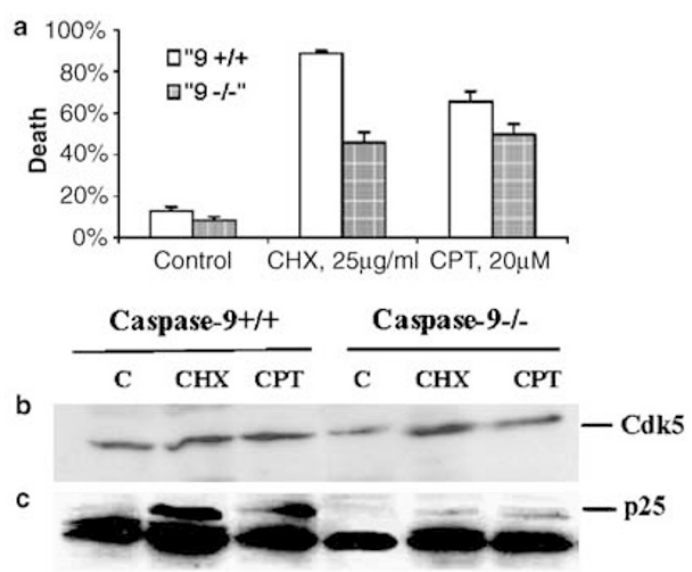

Figure 3 Cdk5/p25 activation during cell death does not require a functional apoptosome. (A) Cdk5 activation during cell death is Apaf-1-independent. (a) Apaf-1 mutant mouse embryos (ED 13.5) were fixed and sectioned as described in Materials and Methods. TUNEL assay and immunohistochemistry study were performed on near-serial sections for comparison. TUNEL assay demonstrates cells with fragmented DNA in the periphery of liver in Apaf-1 knockout embryo and immunohistochemistry using Cdk5 antibody shows cells expressing Cdk5 protein in the same region. Magnification, $\times 100$. (b-d) Cdk5 is activated during cell death in both wild-type and Apaf-1-I- MEFs. Wild-type and Apaf-1-1MEFs were exposed to CHX $(25 \mu \mathrm{g} / \mathrm{ml})$ or CPT $(20 \mu \mathrm{M})$ for $36 \mathrm{~h}$. Cell death was measured by trypan blue (b), and Cdk5 protein (c) and p25 production (d) was examined by immunoblotting of proteins from treated cells using Cdk5 or p35 antibody. (B) Cdk5 is activated during cell death in both wild-type and caspase9-/- MEFs. Wild-type and caspase-9-/ - MEFs were exposed to CHX (25 $\mu \mathrm{g} /$ $\mathrm{ml}$ ) or CPT $(20 \mu \mathrm{M})$ for $24 \mathrm{~h}$. Cell death was measured by trypan blue (a), and Cdk5 protein (b) and p25 production (c) was examined by immunoblotting of proteins from treated cells using Cdk5 or p35 antibody and $46 \%$ cell death in wild-type and caspase-9-/- cells, respectively. CPT killed $65 \%$ wild type and $50 \%$ caspase- $9-1$ - cells (Figure 3B, a). Cdk5 expression did not differ between wild-type and caspase-9-deficient cells (Figure 3B, b). p25 was generated where cell death was induced in both cells, and the level of the p25 induction (Figure 3B, c) corresponded with that of cell death measured by TB exclusion (Figure 3B, a). Thus, Cdk5 is activated whether or not caspase- 9 is present.

Therefore, both Apaf-1 and caspase- 9 are dispensable for Cdk5 activation during cell death, and Cdk5 can be activated in apoptosome-independent cell death.

\section{Cdk5 can be activated in the absence of caspase-3}

Caspase- 3 is the primary effector caspase. We therefore investigated the relationship of Cdk5 activation to activation of caspase-3. TUNEL assay and immunohistochemistry were

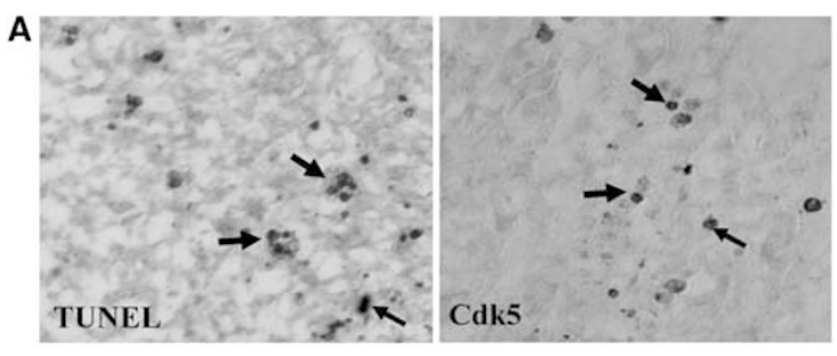

B

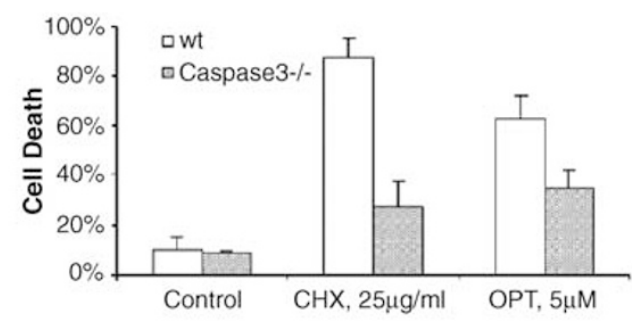

C

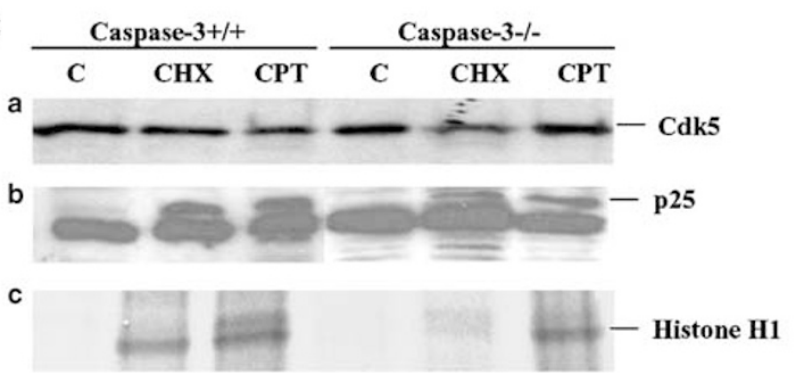

Figure $4 \quad$ Cdk5/p25 activation during cell death does not require caspase-3 activity. (A) Caspase-3 knockout mouse embryos (ED 13.5) were fixed and sectioned as described in Materials and Methods. Cell death and Cdk5 expression in the brain of caspase- 3 knockout mouse embryos were examined by TUNEL and immunohistochemistry, respectively. TUNEL assay demonstrates cells with fragmented DNA (left panel, black arrows) in the brain of caspase-3 knockout embryo, and Cdk5 antibody reveals cells expressing Cdk5 protein (right panel, black arrows) in the same brain region. Magnification, $\times 40$. (B, C) Wildtype and caspase-3-I- MEFs were exposed to $\mathrm{CHX}$ or CPT for $24 \mathrm{~h}$. Cell death was measured by trypan blue exclusion assay (B). Although cell death was reduced in the knockouts, when it occurred, Cdk5 amounts were not changed (C, a) but p25 was produced (C, b) and the kinase was activated (C, c), indicating that activation does not require caspase-3 


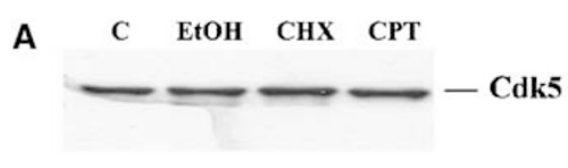

B

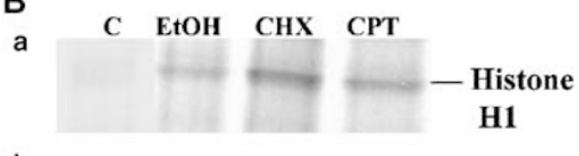

b

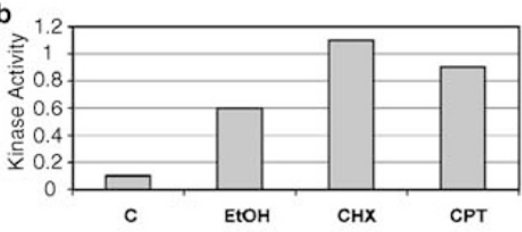

C

a

C EtOH CHX CPT
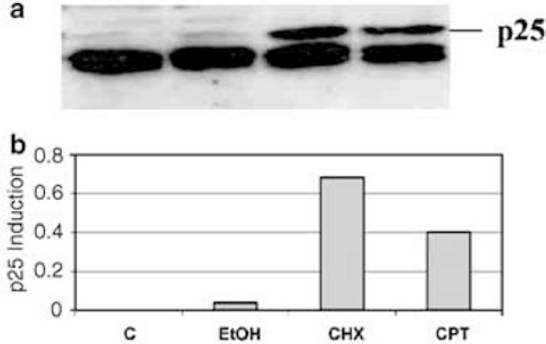

D C EtOH CHX CPT

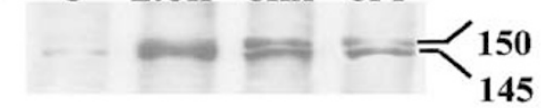

E

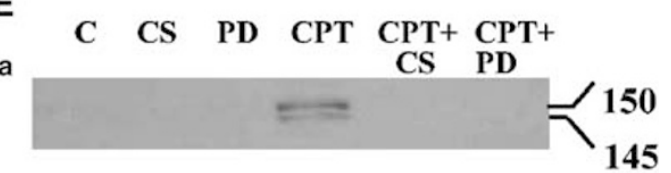

145
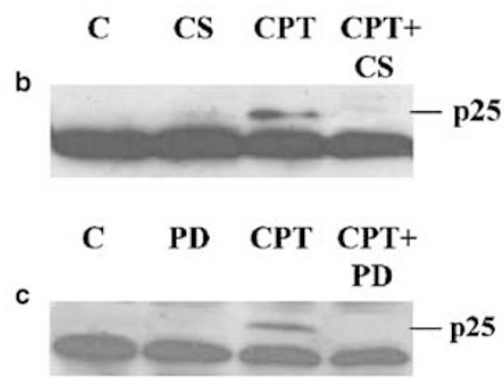

d ${ }^{120} 1$ aNo Inhibitor
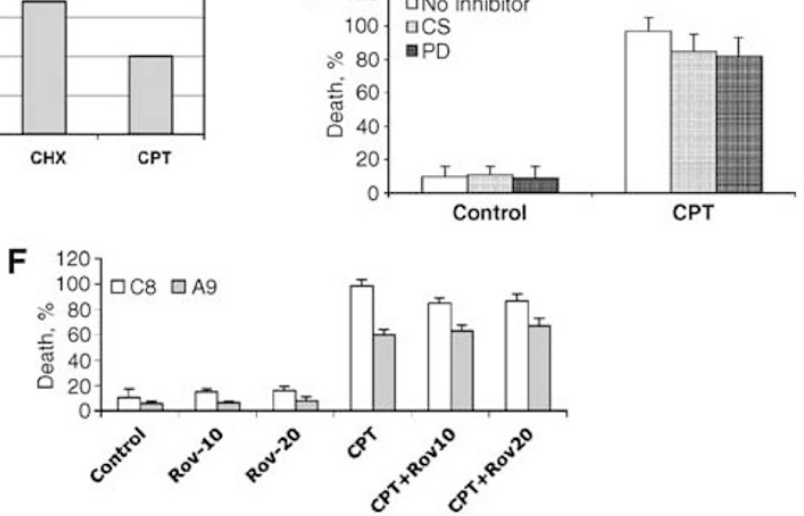

Figure 5 Calpain-mediated p25 production correlates with Cdk5 activation during induced cell death in non-neuronal cells. (A-D) $\mathrm{C} 8$ cells were challenged with EtOH, $\mathrm{CHX}$ or CPT for $18 \mathrm{~h}$. Cells were collected and lysed with RIPA buffer. (A) Immunoblot probed with Cdk5 antibody of equal protein samples as noted above. There is no significant difference in the amount of $\mathrm{Cdk} 5$ protein expressed. (B) Kinase activity of $\mathrm{Cdk5}$ immunoprecipitate was determined using histone $\mathrm{H} 1$ as an in vitro substrate in the presence of $\gamma\left[{ }^{32} \mathrm{P}\right]$ ATP. The incorporated $\gamma\left[{ }^{32} \mathrm{P}\right]$ in phosphorylated histone $\mathrm{H} 1$ was resolved on a $12.5 \%$ acrylamide gel and identified by autoradiography (a) and quantified by densitometry (b). Kinase activity is increased by the toxins. (C) Immunoblot of lysates probed with p35 antibody (a) to identify p25 as quantified by densitometry (b). p25 is activated by all three toxins, but especially by CHX and CPT. (D) Immunoblot probed with spectrin antibody. Calpain activity was determined by examining the production of specific SBDPs at 150 and $145 \mathrm{kDa}$, resulting from cleavage of nonerythroid $\alpha$-spectrin by calpain. Calpain is activated in all three experimental situations. (E) C8 cells were treated with CPT $(20 \mu \mathrm{M})$ for $18 \mathrm{~h}$, in the presence or absence of either of the two calpain inhibitors, CS $(10 \mu \mathrm{M})$ or PD $(10 \mu \mathrm{M})$. Cells were then collected and lysed with RIPA buffer. Immunoblotting using spectrin antibody (a) confirms that CS or PD inhibits calpain activation, and immunoblots probed with p35 antibody (b and c) demonstrate that CS (b) and PD (c) block cleavage of p35 to p25. Trypan blue exclusion (d) shows that neither CS nor PD protected C8 cells from CPT-triggered cell death. (F) Roscovitine does not protect cells with either wild-type (C8) or p53 knockout (A9) from CPT-induced cell death. C8 and A9 cells were treated with CPT $(20 \mu \mathrm{M})$ in the presence or absence of roscovitine $(10$ or $20 \mu \mathrm{M})$ for $18 \mathrm{~h}$. Cell death was measured by trypan blue staining

conducted on near-serial sections of ED13.5 caspase-3 null mouse embryos. TUNEL assay showed many dead cells containing fragmented DNA in the trigeminal region (Figure 4A, left panel, black arrows). This suggested that some cells died in a caspase-3-independent manner, but were still TUNEL positive. Cdk5 protein (active Cdk5) was also expressed in many cells in the same area on an adjacent section (Figure 4A, right panel, black arrows), indicating caspase-3-independent Cdk5 expression and activation in dying cells. In addition to the dying trigeminal cells, we also found cell death in the liver, dorsal root ganglia, and other regions (data not shown).
To further confirm the in vivo data, we used an in vitro system, in which both wild-type and caspase-3-/- primary mouse embryonic fibroblast cells were exposed to $\mathrm{CHX}$ $(25 \mu \mathrm{g} / \mathrm{ml})$ or CPT $(20 \mu \mathrm{M})$ for $24 \mathrm{~h}$. Cells lacking caspase-3 were more resistant to induction of cell death by $\mathrm{CHX}$ or CPT. In all, 27 and $35 \%$ of caspase-3-/- cells were killed by $\mathrm{CHX}$ and CPT, respectively, in contrast to $87 \%$ cells killed by $\mathrm{CHX}$ and $63 \%$ by CPT in wild-type cells (Figure 4B). The level of Cdk5 expression remained constant in both types of cells (Figure 4C, a). However, p25 was generated only when cell death was induced, and its level corresponded to the level of cell death (Figure 4C, b). 
To further verify whether Cdk5 was activated during cell death induced in caspase 3-/- cells, we performed Cdk5 kinase assay using histone $\mathrm{H} 1$ as an in vitro substrate. The phosphorylated histone $\mathrm{H} 1$ band at $33 \mathrm{kDa}$ indicated activation of Cdk5 in both wild-type and caspase-3-/- cells induced to die by $\mathrm{CHX}$ and CPT. The intensity of the band corresponded to that of the p25 band and to the level of induced cell death (Figure 4C, c).

Thus, caspase-3 is not required for p25-mediated Cdk5 activation during cell death.

\section{Cdk5 is not necessary for cell death in non-neuronal $\mathbf{C 8}$ cells}

Having established that apoptotic cell death could be induced in the MEF C8 cells, we used these cells to examine the activation of Cdk5 activity and its regulation. The level of Cdk5 protein was equal in both control and cells exposed to the three toxins (Figure 5A), as we had seen in dying cells of developing mouse embryos. ${ }^{24,28}$ However, we found little, if any, activity of Cdk5 kinase in the control, but substantial activity in all exposed samples (Figure 5B, a). The level of Cdk5 kinase activity quantified by densitometry (Figure 5B, b) approximated the level of cell death (Figure 5A).

p25, presumptively generated from p35, is an activator of Cdk5, is involved in neuronal cell death, and is the only Cdk5 interacting protein identified in dying cells. ${ }^{28}$ Here we examined the generation of p25 in non-neuronal cells in relation to cell death induced by the different reagents. By WB, p25 induction was seen for all the three treatments (Figure 5C, a) and the level, as quantified by densitometry (Figure $5 \mathrm{C}, \mathrm{b}$ ), approximated that of cell death (Figure 1A) and correlated with Cdk5 activity, as measured by the histone 1 kinase assay (Figure 5B).

Calpain is the only protease identified as cleaving p35 to form p25. Calpain activation can be determined by the cleavage of its endogenous substrate spectrin to form specific spectrin breakdown products (SBDPs) at 150 and $145 \mathrm{kDa}^{61}$ In exposed C8 cells, anti-spectrin antibody detected a dual band at 150 and $145 \mathrm{kDa}$, indicating calpain activation (Figure 5D).

The level of calpain activation (Figure 5D) corresponded to the level of p25 generated (Figure $5 \mathrm{C}$ ). The relationship between calpain activation and generation of p25 was further demonstrated by the use of two specific calpain inhibitors, calpastatin (CS) peptide (an endogenous inhibitor of calpain) and PD150606 (PD, a synthetic inhibitor). In C8 cells exposed to CPT in the presence of either CS or PD, SBDP bands representing calpain activation were not present as expected (Figure 5E, a), and the p25 band failed to appear as well (Figure $5 \mathrm{E}, \mathrm{b}$ and $\mathrm{c}$ ). Similar results were observed in $\mathrm{C} 8$ cells treated with $\mathrm{EtOH}$ and $\mathrm{CHX}$ (data not shown). Since we and many others have demonstrated that p35/p25 acts directly upstream of Cdk5 activation and p25 production is a reasonable measure of Cdk5 activation due to its more accessible measurement, these results document that Cdk5 activation is induced by calpainmediated p25 production during cell death in cells other than neurons.
However, although inhibition of calpain activity by either CS or PD abolished Cdk5 activation, it failed to protect cells from death trigged by CPT. In C8, either CS or PD alone did not induce cell death above the basal level in untreated control cells, and neither inhibitor significantly protected $\mathrm{C} 8$ from CPT-induced apoptosis (Figure 5D, d). To more directly link Cdk5 activation and apoptosis, we further exposed both C8 and A9 (p53-/-) cells to CPT in the presence or absence of roscovitine, a widely used Cdk5 inhibitor. At low concentrations as we used in our experiment, roscovitine specifically inhibits Cdk5, while sparing other Cdks. ${ }^{62}$ In both C8 and A9, $5-20 \mu \mathrm{M}$ rovcovitine did not affect the level of cell death induced by CPT after $18 \mathrm{~h}$ (Figure 5F). Therefore, Cdk5 activation does not cause cell death and inhibition of Cdk5 activity will not protect cells.

\section{Discussion}

In this paper, we demonstrate that the finding that p25 is generated when Cdk5 is activated in neuronal cells applies also to cells other than neurons, and we extend the finding by dissociating this activation from several well-known pathways of apoptosis. As expected, p53 protects cells at low doses of $\mathrm{CHX}$ and CPT, but high levels of these very toxic drugs ultimately lead to cell death although with different kinetics, and this death occurs with Cdk5 activation and p25 generation. These findings corroborate those of Neet et al., who observed that delayed apoptosis occurs even in p53-defective NGF-deprived PC-12 cells. ${ }^{63}$ In our experiments, the fact that EtOH kills far fewer A9 cells (12\% after $18 \mathrm{~h}$ compared to $54 \%$ of $\mathrm{C} 8$ ) indicates that EtOH lethality in these fibroblasts is dependent on p53. However, whether or not cell death requires a functional p53 pathway, the Cdk5/p25 activation correlates with the induction of cell death.

Cdk5 is activated even when the intrinsic pathway is not. The formation of an active apoptosome (cytochrome c/Apaf1) and consequent caspase- 9 and 3 activation define the intrinsic cell death pathway. ${ }^{64}$ Here we demonstrate that Cdk5 is activated when cells die in the absence of Apaf-1, caspase9, or -3. Cdk5 is also activated in CPT-induced cell death in C8 (wild-type) fibroblasts in the presence of the pan-caspase inhibitor zVAD-FMK $(50 \mu \mathrm{M})$, further documenting a general correlation between Cdk5 activation and cell death, regardless of caspase activation.

Since caspase activity is necessary for the classical characteristics of apoptosis, such as internucleosomal DNA fragmentation, ${ }^{65}$ the deaths in the Apaf-1, caspase- $9,-3$ knockouts, and in the presence of zVAD-FMK are presumptively nonapoptotic or represent a variation of apoptosis. If so, we have demonstrated a correlation between Cdk5 activation and both classical apoptotic and nonapoptotic or nonclassical apoptotic cell death. Caspase- 3 activation, when present, coincides with the activation of Cdk5, but lack of caspase-3 does not hinder the cell death-related activation of Cdk5, indicating that Cdk5 activity is independent of caspase-3 during cell death. Although we did not directly test the correlation with caspase-3, inhibition of Cdk5 does not delay cell death. Sandal et al. ${ }^{66}$ argued that Cdk5 activation is located upstream of caspase-3 activation and that Cdk5 
activity is needed for cleavage of pro-enzyme caspase- 3 to its active $(17 \mathrm{kDa})$ form, in cAMP-induced apoptosis in rat leukemia cells. However, Li et al. ${ }^{41}$ demonstrated caspase-3 activation in the brain of Cdk5 null mouse embryos during cell death, indicating Cdk5-independent caspase-3 activation in neuronal cell death. Our results are more consistent with those of Li et al. The discrepancy may perhaps be ascribed to the different systems utilized.

The activation and generation of p25 are coincident with the activation of calpain. However, although blockage of calpain using either CS or PD prevents activation of Cdk5 (Figure 5E, $b$ and $c$ ), it does not reduce the level of cell death (Figure 5E, d). Furthermore, we have conducted studies where inhibition of Cdk5 activity using either pharmacological inhibitors, such as roscovitine, or dominant-negative mutants cannot protect cells from cell death in which Cdk5 is usually activated (Figure 5F; DN, data not shown). Therefore, our data suggest that $\mathrm{Cdk5/p25}$ activation is a consequence rather than a cause of cell death in neuronal and non-neuronal cells. That neurons from Cdk5 knockout mice can die via apoptosis supports our finding. ${ }^{41}$

How Cdk5 is activated seems to vary according to the experimental paradigm. It has been shown that Cdk7, purified from bovine brain, is a Cdk5-activating kinase that phosphorylates Cdk5 at Ser159 and enhances Cdk5/p25 activity. ${ }^{67}$ Cdk5 can also be activated without p25 in rat cerebellar granule neurons following glutathione depletion. ${ }^{42}$ Our data indicate activation by p25 in these mesodermal cells. The fact that Cdk5 protein does not change in either treated or untreated $\mathrm{C} 8$ and $\mathrm{A} 9$ cells or other cells with specific knockouts supports the argument that Cdk5 is a relatively stable protein and that its activation during cell death is not regulated by synthesis or degradation of protein. ${ }^{28}$

Cdk5 may mediate neuronal apoptosis through two distinct mechanisms, a cytoplasmic mechanism that leads to cytoskeleton disruption ${ }^{6}$ and a nuclear mechanism that interferes with the transcription of prosurvival genes. ${ }^{68}$ Since the presence or absence of active Cdk5 does not appear to affect apoptosis or nonapoptotic cell death, the significance of these findings is unclear.

We conclude that Cdk5 protein is present in many, if not all, types of cells in vivo and in vitro, and that this protein is activated upon induction of cell death. Activation of Cdk5 is dependent on generation of p25 from p35 by means of activated calpain, and is independent of p53, apoptosome, caspase-3, and -9. However, a cell can also die without activation of Cdk5 by p25 generation, thus producing a death either independent of Cdk5 or relying on activation of Cdk5 by unidentified factors. We are examining the latter possibility, as we continue to explore the significance of Cdk5 activation in cell death.

\section{Materials and Methods}

\section{Antibodies and reagents}

Chemical reagents were ordered from Sigma (St Louis, MO, USA), unless otherwise mentioned. The calpain inhibitors, CS peptide (Cat\# 208902) and PD (Cat\# 513022), were obtained from CalBiochem (La Jolla, CA, USA). The antibodies used in this paper include anti-Cdk5 (C-8), anti-p35
(C-19), and anti-PARP (H-250) antibodies from Santa Cruz Biotechnology (Santa Cruz, CA, USA), anti-active caspase-3 antibody from BD Biosciences (San Diego, CA, USA), and anti-spectrin antibody from Chemicon International (Temecula, CA, USA).

\section{Cell culture and treatment}

C8 and $A 9$ cells are mouse embryonic fibroblast cell lines transformed with E1A and ras, with $\mathrm{C} 8 \mathrm{p} 53+/+$ and $\mathrm{A} 9 \mathrm{p} 53-/-$ (gift from Dr. Scott Lowe, CSHL). Cells were maintained in Dulbecco's modified Eagle medium (DMEM, Life Technologies, Rockville, MD, USA) supplemented with $10 \%$ fetal bovine serum, $50 \mathrm{U} / \mathrm{ml}$ penicillin, and $100 \mu \mathrm{g} / \mathrm{ml}$ streptomycin, at $37^{\circ} \mathrm{C}$, in a humidified atmosphere of $7.5 \% \mathrm{CO}_{2}$. At $80 \%$ confluence, cells were exposed in DMEM containing $1 \%$ FBS to $2.5 \%$ $\mathrm{EtOH}, 25 \mu \mathrm{g} / \mathrm{ml}$ cycloheximide (CHX, dissolved in $\mathrm{EtOH}$ ), or $20 \mu \mathrm{M} \mathrm{CPT}$ (dissolved in DMSO), for $18 \mathrm{~h}$. For the kinetic study of cells exposed to $20 \mu \mathrm{M} \mathrm{CPT}$, cells were collected at $0,3,6,8,12,15$, and $18 \mathrm{~h}$. To block calpain activation induced by CPT in both $\mathrm{C} 8$ and $\mathrm{A} 9$ cells, two calpain inhibitors, $10 \mu \mathrm{M}$ CS or $10 \mu \mathrm{M} \mathrm{PD}$, were coadministered with CPT and cells were incubated for $18 \mathrm{~h}$. To inhibit Cdk5 activation, cells were treated with roscovitine alone or in combination with $\mathrm{CPT}$ for $18 \mathrm{~h}$.

\section{Cell death by trypan blue}

Dead and dying cells lose membrane integrity, allowing the preferential uptake of vital dye trypan blue. ${ }^{69}$ Following exposure to toxins, cells were pelleted and washed with PBS. In all, $100 \mu$ l of well-suspended cells was mixed with $100 \mu \mathrm{l}$ of $0.4 \%$ trypan blue solution in phosphate-buffered saline (PBS, $145.4 \mathrm{mM} \mathrm{NaCl}, 2.68 \mathrm{mM} \mathrm{KCl}, 10 \mathrm{mM} \mathrm{Na} \mathrm{HPO}_{4}, 1.8 \mathrm{mM}$ $\mathrm{KH}_{2} \mathrm{PO}_{4}, \mathrm{pH}$ 7.4), and left at room temperature (RT) for $5 \mathrm{~min}$. Cells were then viewed under a light microscope; blue cells were considered nonviable.

\section{Detection of DNA fragmentation by agarose gel electrophoresis}

Cells were lysed in lysis buffer $(0.2 \%$ Triton X-100, $10 \mathrm{mM}$ Tris/HCl $10 \mathrm{mM}$ EDTA, pH 7.5). The cell lysate was incubated on ice for $15 \mathrm{~min}$, followed by centrifuging at $4^{\circ} \mathrm{C}$ at $13000 \mathrm{rpm}$ for $30 \mathrm{~min}$. The supernatant containing the low-molecular-mass DNA was incubated with RNase $(100 \mu \mathrm{g} / \mathrm{ml})$ for $1 \mathrm{~h}$ and then extracted twice with equal volumes of phenol/ chloroform/isoamyl alcohol $(24: 24: 1)$ and once with chloroform/isoamyl alcohol $(24: 1)$. The extracted low-molecular-mass DNA was precipitated with $300 \mathrm{mM} \mathrm{NaCl}$ and 2.5 volume of $\mathrm{EtOH}$ at $-20^{\circ} \mathrm{C}$ overnight and spun at $13000 \mathrm{rpm}$ for $30 \mathrm{~min}$ at $4{ }^{\circ} \mathrm{C}$. The pellet was washed with $70 \% \mathrm{EtOH}$ once, air dried, and suspended in $10 \mathrm{mM}$ Tris/ $\mathrm{HCl}, 1 \mathrm{mM}$ EDTA, $\mathrm{pH} 8.0$. Low-molecular-mass DNA from equal numbers of cells was run on $2 \%$ agarose gel. Separated DNA bands were visualized by ethidium bromide staining of the gel.

\section{Animals, tissue, and slide preparation}

Mice (p53 heterozygous mice C57BL/6J-Trp53 ${ }^{\text {tmlTy }}$ (Jackson Laboratories, Bar Harbor, ME, USA) and caspase-3 heterozygous mice (gift from Dr. Flavell, Yale University)) were mated overnight, and early next morning females were checked for vaginal plugs. Positive females were designated as gestational day 0.5 . On gestational day 13.5 , females were killed by cervical dislocation and the embryos were removed. Freshly dissected tissue samples were fixed in $4 \%$ paraformaldehyde by shaking at $4^{\circ} \mathrm{C}$ 
overnight, then washed with PBS and partially dehydrated by immersing in $20 \%$ sucrose at $4{ }^{\circ} \mathrm{C}$ by shaking for $24 \mathrm{~h}$. Embryos were then embedded in OTC compound (Miles, Elkhart, IN, USA) for frozen blocks, which can be stored at $-80^{\circ} \mathrm{C}$ and sections were made on Vectabond ${ }^{\mathbb{R}}$ slides.

\section{PCR genotyping of p53 knockout mice}

Genotyping of embryos was performed according to the protocol recommended by Jackson Laboratories (http://www.jax.org/resources/ documents/imr/supp_proto.html). Two sets of primers were used for p53: $5^{\prime}$-CTT GGG TGG AGA GGC TAT TC- $3^{\prime}$ and $5^{\prime}$-AGG TGA GAT GAC AGG AGA TC-3'; $5^{\prime}$-ATA GGT CGG CGG TTC AT-3' and $5^{\prime}$-CCC GAG TAT CTG GAA GAC AG-3'. Three primers were used for caspase-3: $5^{\prime}$ CTT GGG TGG AGA GGC TAT TC- $3^{\prime}$ and $5^{\prime}$-AGG TGA GAT GAC AGG AGA TC-3'; 5'-ATA GGT CGG CGG TTC AT- $3^{\prime}$ and $5^{\prime}$-CCC GAG TAT CTG GAA GAC AG-3'. Briefly, the hind limb was lysed in $170 \mu$ of lysis solution (50 mM Tris, pH 8.3, $100 \mathrm{mM} \mathrm{NaCl}, 5 \mathrm{mM}$ EDTA, 0.8\% SDS) and $30 \mu$ of Proteinase $\mathrm{K}$ solution $(10 \mathrm{mg} / \mathrm{ml})$ at $55^{\circ} \mathrm{C}$ for $5 \mathrm{~h}$ or overnight. After centrifuging at $13000 \mathrm{rpm}$ for $15 \mathrm{~min}$, the supernatant containing DNA was precipitated using the same volume of $100 \%$ isopropyl alcohol. The DNA pellet obtained by centrifuging at $13000 \mathrm{rpm}$ for $15 \mathrm{~min}$ was dissolved in autoclaved $\mathrm{dd}_{2} \mathrm{O}$ and stored at $-20^{\circ} \mathrm{C}$. In all, 10-200 ng of the extracted DNA was used for PCR. This PCR assay applied the 'touching down cycling' technique. For the first 12 cycles, the annealing temperature, which started at $64^{\circ} \mathrm{C}$, was reduced by $0.5^{\circ}$ per cycle. For the remaining 25 cycles, the annealing temperature stayed at $58^{\circ} \mathrm{C}$. The PCR products were separated by gel electrophoresis on a $1.5 \%$ agarose gel. P53 or caspase- 3 wild type gave a band at 600 or 320 bp, and their knockout counterparts showed a band at 280 or $300 \mathrm{bp}$, respectively.

\section{DNA fragmentation assay by TUNEL}

DNA fragmentation was detected by using TUNEL peroxidase (TUNEL POD) combined with nonisotopic digoxigenin-11-dUTP and terminal transferase according to our previously published method ${ }^{24}$ and the manufacturer's instruction (Roche Molecular Biochemicals, Germany). Briefly, slides were incubated with permeabilization solution $(0.1 \%$ Triton $\mathrm{X}-100$ in $0.1 \%$ sodium citrate) on ice for $2 \mathrm{~min}$, and endogenous peroxidase activity was quenched with $0.3 \%$ hydrogen peroxide in methanol at RT for $30 \mathrm{~min}$. After two rinses in PBS, TUNEL reaction mixture ( 9 volume of TUNEL label and 1 volume of TUNEL enzyme) was applied to slides, which were incubated for $30 \mathrm{~min}$ at $37^{\circ} \mathrm{C}$ followed by three washes with PBS. TUNEL POD was then applied to the slides to bind to the FITC-dUTP enzymatically added to the free end of the oligonucleotide and visualized with DAB (diaminobenzidine, Research Genetics, Huntsville, AL, USA). The sections were counterstained with methylene blue and mounted with Permount ${ }^{\mathbb{R}}$ (Fisher Scientific, Burr Ridge, IL, USA).

\section{Immunohistochemistry}

In situ levels of specific proteins were estimated using the AvidinBiotinylated-peroxidase Complex $(A B C)$ kit (Vectastain ABC kit, Vector Laboratory, Burlingame, CA, USA). Sections were quenched with $0.3 \%$ hydrogen peroxide in methanol at RT for $20 \mathrm{~min}$ to abolish endogenous peroxidase activity. After three washes with $1 \times$ PBST (0.1\% Tween 20 in PBS), sections were incubated in blocking solution at RT for $1 \mathrm{~h}$, and treated with primary antibody $(0.5 \mu \mathrm{g} / \mathrm{ml}$ for Cdk5 and $\mathrm{p} 35,0.1 \mu \mathrm{g} / \mathrm{ml}$ for caspase-3) (Santa Cruz Biotechnology, Santa Cruz, CA, USA) at $4^{\circ} \mathrm{C}$ in a humidified chamber overnight. Following three washes with PBST, secondary biotinylated antibody was applied to the sections for $1 \mathrm{~h}$ at RT. Sections were then washed with PBST for three times and incubated with $A B C$ reagent for $2 h$ at RT. Sections were washed with PBST for three times before being visualized with $D A B$, counterstained with methylene blue, and mounted with Permount.

\section{Western blot}

Cells or tissues were lysed in RIPA buffer (50 mM Tris, pH 7.5, $150 \mathrm{mM}$ $\mathrm{NaCl}, 1 \%$ Triton $\mathrm{X}-100,0.1 \%$ SDS, $0.5 \%$ sodium deoxycholate, $2 \mathrm{mM}$ EDTA) supplemented fresh with protease inhibitor cocktail tablets (Boehringer Mannheim, Germany), and cell/tissue debris were removed by centrifugation at $13000 \mathrm{rpm}$ for $30 \mathrm{~min}$ at $4^{\circ} \mathrm{C}$. Protein concentration was determined using the Bio-Rad microassay (Bio-Rad laboratories, Hercules, CA, USA). Equal amounts of protein were run on $8,12.5$ or $15 \%$ SDS-polyacrylamide gels after addition of equal volumes of $2 \times$ Laemmli loading buffer (100 mM Tris, pH 7.5, 4\% SDS, $20 \%$ glycerol, $0.002 \%$ bromophenol blue). ${ }^{70}$ After protein transfer, nitrocellulose membrane blots were blocked with $5 \%$ non-fat dry milk in PBST for $30 \mathrm{~min}$ at RT and incubated with primary antibody $(0.5 \mu \mathrm{g} / \mathrm{ml}$ for Cdk5 or p35 or caspase-3, $0.1 \mu \mathrm{g} / \mathrm{ml}$ for spectrin and PARP) on the shaker overnight at $4^{\circ} \mathrm{C}$. After three washes with PBST, blots were incubated with horseradish peroxidase (HRP)-conjugated goat anti-rabbit antibody (Jackson Immuno Research Laboratory, West Grove, PA, USA) for $1 \mathrm{~h}$ at RT, followed by three washes. The immune complexes were detected by chemiluminescence (ECL Plus kit, Amersham, Chicago, IL, USA) and exposed to an autoradiographic film.

\section{In vitro histone $\mathrm{H} 1$ kinase assays}

Cdk5 kinase activity was assayed as described by Zhang et al. ${ }^{5}$ Equal amounts of lysates from different cell samples were incubated with $1.5 \mu \mathrm{g} /$ $\mathrm{ml} \mathrm{Cdk5}$ antibody for $1 \mathrm{~h}$ at $4^{\circ} \mathrm{C}$, and then purified by the addition of protein A-Sepharose (Boehringer Mannheim, Germany). The precipitated beads were equilibrated in kinase buffer $\left(50 \mathrm{mM}\right.$ Tris, $\mathrm{pH} 7.5,10 \mathrm{mM} \mathrm{MgCl}_{2}$, $1 \mathrm{mM}$ DTT, $20 \mathrm{mM}$ EGTA, $0.1 \mathrm{mM}$ sodium vanadate, $80 \mathrm{mM} \beta$ glycerophosphate) and collected by centrifugation. Histone $\mathrm{H} 1$ kinase assays were performed in kinase buffer supplemented with $0.1 \mu \mathrm{Ci} / \mathrm{ml}$ $\left[\gamma^{32} \mathrm{P}\right]$ ATP $(6000 \mathrm{Ci} / \mathrm{mM})$ (Amersham Pharmacia Biotech., Piscataway, NJ, USA), $10 \mathrm{mM} \mathrm{ATP,} 50 \mu \mathrm{g} / \mathrm{ml}$ calf thymus histone $\mathrm{H} 1$ (Boehringer Mannheim, Germany), and $5 \mu \mathrm{M}$ cAMP-dependent protein kinase inhibitor (Sigma, St Louis, MO, USA) at $30^{\circ} \mathrm{C}$ for $30 \mathrm{~min}$. An equal volume of $2 \times$ Laemmli buffer was added to each sample before they were denatured at $100^{\circ} \mathrm{C}$ for $2 \mathrm{~min}$. Following electrophoresis, gels were fixed, dried, and exposed to film. The intensity of the bands was quantified using a Storm Imaging System (Molecular Dynamics Inc., Sunnyvale, CA, USA).

\section{Condensed nuclei stained by bis-benzimide}

The DNA fluorochrome bis-benzimide (Hoechst 33258, Sigma, St Louis, MO, USA) was used to stain the fragmented nuclei of apoptotic cells. Briefly, cells were trypsinized, pelleted, and washed once with ice-cold PBS. The cells were then resuspended and fixed in $3 \%$ paraformaldehyde solution (in PBS) for 30 min, washed with ice-cold PBS, and incubated with $16 \mu \mathrm{g} / \mathrm{ml}$ bis-benzimide (in PBS) for $25 \mathrm{~min}$ at RT. Finally, the cells were washed with ice-cold PBS once and resuspended in PBS. A volume of $20 \mu \mathrm{l}$ of the cell suspension was evenly distributed on a slide and coverslipped to be viewed under an Eclipse TE300 microscope (Nikon Inc., Melville, NY, USA). 


\section{Acknowledgements}

We would like to thank Drs Richard Flavell of Yale University for providing us with caspase-3 knockout mice, Scott Lowe of Cold Spring Harbor Laboratory for providing us with Apaf-1 and caspase-9 null MEFs, and Francesco Cecconi of University of Rome Tor Vergata for providing Apaf-1 null mouse embryo slides. We also would like to thank Dr Richard Lockshin for his great insight and comments in reviewing this manuscript. This work was in part supported by a grant from PSC CUNY and was in part presented in Dr Lin Lin's thesis work.

\section{References}

1. Lew J, Beaudette K, Litwin CM and Wang JH (1992) Purification and characterization of a novel proline-directed protein kinase from bovine brain. J. Biol. Chem. 267: 13383-13390

2. Meyerson M, Enders GH, Wu CL, Su LK, Gorka C, Nelson C, Harlow E and Tsai LH (1992) A family of human cdc2-related protein kinases. EMBO J. 11: 2909-2917

3. Tsai LH, Takahashi T, Caviness Jr VS and Harlow E (1993) Activity and expression pattern of cyclin-dependent kinase 5 in the embryonic mouse nervous system. Development 119: 1029-1040

4. Gao CY, Zakeri Z, Zhu Y, He H and Zelenka PS (1997) Expression of Cdk5, p35, and Cdk5-associated kinase activity in the developing rat lens. Dev. Genet. 20: 267-275

5. Zhang Q, Ahuja HS, Zakeri ZF and Wolgemuth DJ (1997) Cyclin-dependent kinase 5 is associated with apoptotic cell death during development and tissue remodeling. Dev. Biol. 183: 222-233

6. Dhavan R and Tsai LH (2001) A decade of CDK5. Nat. Rev. Mol. Cell. Biol. 2: 749-759

7. Nikolic M, Dudek H, Kwon YT, Ramos YF and Tsai LH (1996) The cdk5/p35 kinase is essential for neurite outgrowth during neuronal differentiation. Genes Dev. 10: 816-825

8. Fu WY, Wang JH and Ip NY (2002) Expression of Cdk5 and its activators in NT2 cells during neuronal differentiation. J. Neurochem. 81: 646-654

9. Kwon YT, Gupta A, Zhou Y, Nikolic M and Tsai LH (2000) Regulation of Ncadherin-mediated adhesion by the p35-Cdk5 kinase. Curr. Biol. 10: 363-372

10. Xie $Z$ and Tsai LH (2004) Cdk5 phosphorylation of FAK regulates centrosomeassociated miocrotubules and neuronal migration. Cell Cycle 3: 108-110

11. Paglini G, Pigino G, Kunda P, Morfini G, Maccioni R, Quiroga S, Ferreira A and Caceres A (1998) Evidence for the participation of the neuron-specific CDK5 activator P35 during laminin-enhanced axonal growth. J. Neurosci. 18: 9858-9869

12. Rosales JL, Nodwell MJ, Johnston RN and Lee KY (2000) Cdk5/p25(nck5a) interaction with synaptic proteins in bovine brain. J. Cell Biochem. 78 $151-159$

13. Tomizawa K, Sunada S, Lu YF, Oda Y, Kinuta M, Ohshima T, Saito T, Wei FY Matsushita M, Li ST, Tsutsui K, Hisanaga S, Mikoshiba K, Takei K and Matsui H (2003) Cophosphorylation of amphiphysin I and dynamin I by Cdk5 regulates clathrin-mediated endocytosis of synaptic vesicles. J. Cell Biol. 163: 813-824

14. Lee SY, Wenk MR, Kim Y, Nairn AC and De Camilli $P$ (2004) Regulation of synaptojanin 1 by cyclin-dependent kinase 5 at synapses. Proc. Natl. Acad. Sci. USA 101: $546-551$

15. Bibb JA, Snyder GL, Nishi A, Yan Z, Meijer L, Fienberg AA, Tsai LH, Kwon YT, Girault JA, Czemik AJ, Huganir RL, Hemmings Jr HC, Naim AC and Greengard P (1999) Phosphorylation of DARPP-32 by Cdk5 modulates dopamine signalling in neurons. Nature 402: 669-671

16. Chergui K, Svenningsson $P$ and Greengard P (2004) Cyclin-dependent kinase 5 regulates dopaminergic and glutamatergic transmission in the striatum. Proc. Natl. Acad. Sci. USA 101: 2191-2196

17. Shuang $R$, Zhang L, Fletcher A, Groblewski GE, Pevsner $J$ and Stuenkel EL (1998) Regulation of Munc-18/syntaxin 1A interaction by cyclin-dependent kinase 5 in nerve endings. J. Biol. Chem. 273: 4957-4966

18. Ohshima T, Gilmore EC, Longenecker $G$, Jacobowitz DM, Brady RO, Herrup $K$ and Kulkarmi AB (1999) Migration defects of cdk5(-/-) neurons in the developing cerebellum is cell autonomous. J. Neurosci. 19: 6017-6026
19. Philpott A, Porro EB, Kirschner MW and Tsai LH (1997) The role of cyclindependent kinase 5 and a novel regulatory subunit in regulating muscle differentiation and patterning. Genes Dev. 11: 1409-1421

20. Sahlgren CM, Mikhailov A, Vaittinen S, Pallari HM, Kalimo H, Pant HC and Eriksson JE (2003) Cdk5 regulates the organization of Nestin and its association with p35. Mol. Cell. Biol. 23: 5090-5106

21. Sharma MR, Tuszynski GP and Sharma MC (2004) Angiostatin-induced inhibition of endothelial cell proliferation/apoptosis is associated with the downregulation of cell cycle regulatory protein cdk5. J. Cell. Biochem. 91: 398-409

22. Chen F, Rao J and Studzinski GP (2000) Specific association of increased cyclin-dependent kinase 5 expression with monocytic lineage of differentiation of human leukemia HL60 cells. J. Leukoc. Biol. 67: 559-566

23. Studzinski GP and Harrison JS (2003) The neuronal cyclin-dependent kinase 5 activator p35Nck5a and Cdk5 activity in monocytic cells. Leuk. Lymphoma 44: $235-240$

24. Ahuja HS, James W and Zakeri Z (1997) Rescue of the limb deformity in hammertoe mutant mice by retinoic acid-induced cell death. Dev. Dyn. 208: 466-481

25. Kazzaz JA, Horowitz S, Xu J, Khullar P, Niederman MS, Fein AM, Zakeri Z, Lin $L$ and Rhodes GC (2000) Differential patterns of apoptosis in resolving and nonresolving bacterial pneumonia. Am. J. Respir. Crit. Care Med. 161: 2043-2050

26. Desbarats J, Stone JE, Lin L, Zakeri ZF, Davis GS, Pfeiffer LM, Titus RG and Newell MK (2000) Rapid early onset lymphocyte cell death in mice resistant, but not susceptible to Leishmania major infection. Apoptosis 5: 189-196

27. Mantell LL, Shaffer TH, Horowitz S, Foust III R, Wolfson MR, Cox C, Khullar P, Zakeri Z, Lin L, Kazzaz JA, Palaia T, Scott W and Davis JM (2002) Distinct patterns of apoptosis in the lung during liquid ventilation compared with gas ventilation. Am. J. Physiol. Lung Cell. Mol. Physiol. 283: L31-L41

28. Zhu Y, Lin L, Kim S, Quaglino D, Lockshin RA and Zakeri Z (2002) Cyclin dependent kinase 5 and its interacting proteins in cell death induced in vivo by cyclophosphamide in developing mouse embryos. Cell Death Differ. 9: $421-430$

29. Patrick GN, Zukerberg L, Nikolic M, de la Monte S, Dikkes P and Tsai LH (1999) Conversion of p35 to p25 deregulates Cdk5 activity and promotes neurodegeneration. Nature 402: 615-622

30. Patrick GN, Zukerberg L, Nikolic M, de La Monte S, Dikkes P and Tsai LH (2001) reply: Neurobiologyp25 protein in neurodegeneration. Nature 411: 764-765

31. Lee MS, Kwon YT, Li M, Peng J, Friedlander RM and Tsai LH (2000) Neurotoxicity induces cleavage of p35 to p25 by calpain. Nature 405: 360-364

32. Nath R, Davis M, Probert AW, Kupina NC, Ren X, Schielke GP and Wang KK (2000) Processing of cdk5 activator p35 to its truncated form (p25) by calpain in acutely injured neuronal cells. Biochem. Biophys. Res. Commun. 274: 16-21

33. Bu B, Li J, Davies P and Vincent I (2002) Deregulation of cdk5, hyperphosphorylation, and cytoskeletal pathology in the Niemann-Pick type C murine model. J. Neurosci. 22: 6515-6525

34. Hashiguchi M, Saito T, Hisanaga S and Hashiguchi T (2002) Truncation of CDK5 activator p35 induces intensive phosphorylation of Ser202/Thr205 of human tau. J. Biol. Chem. 277: 44525-44530

35. Kusakawa G, Saito T, Onuki R, Ishiguro K, Kishimoto T and Hisanaga S (2000) Calpain-dependent proteolytic cleavage of the p35 cyclin-dependent kinase 5 activator to p25. J. Biol. Chem. 275: 17166-17172

36. Sisodiya SM, Thom M, Lin WR, Bajaj NP, Cross JH and Harding BN (2002) Abnormal expression of cdk5 in focal cortical dysplasia in humans. Neurosci. Lett. 328: 217-220

37. Smith PD, Crocker SJ, Jackson-Lewis V, Jordan-Sciutto KL, Hayley S, Mount MP, O'Hare MJ, Callaghan S, Slack RS, Przedborski S, Anisman H and Park DS (2003) Cyclin-dependent kinase 5 is a mediator of dopaminergic neuron loss in a mouse model of Parkinson's disease. Proc. Natl. Acad. Sci. USA 100: 13650-13655

38. Tsai LH, Delalle I, Caviness Jr VS, Chae T and Harlow E (1994) p35 is a neuralspecific regulatory subunit of cyclin-dependent kinase 5. Nature 371: 419-423

39. Zheng M, Leung CL and Liem RK (1998) Region-specific expression of cyclindependent kinase 5 (cdk5) and its activators, p35 and p39, in the developing and adult rat central nervous system. J. Neurobiol. 35: 141-159

40. Gupta A, Sanada K, Miyamoto DT, Rovelstad S, Nadarajah B, Pearlman AL, Brunstrom J and Tsai LH (2003) Layering defect in p35 deficiency is linked 
to improper neuronal-glial interaction in radial migration. Nat. Neurosci. 6: 1284-1291

41. Li BS, Zhang L, Takahashi S, Ma W, Jaffe H, Kulkarni AB and Pant HC (2002) Cyclin-dependent kinase 5 prevents neuronal apoptosis by negative regulation of c-Jun N-terminal kinase 3. EMBO J. 21: 324-333

42. Weishaupt JH, Kussmaul L, Grotsch P, Heckel A, Rohde G, Romig H, Bahr M and Gillardon $F(2003)$ Inhibition of CDK5 is protective in necrotic and apoptotic paradigms of neuronal cell death and prevents mitochondrial dysfunction. Mol. Cell. Neurosci. 24: 489-502

43. Lowe SW and Ruley HE (1993) Stabilization of the p53 tumor suppressor is induced by adenovirus $5 \mathrm{E} 1 \mathrm{~A}$ and accompanies apoptosis. Genes Dev. 7: 535-545

44. Clarke AR, Purdie CA, Harrison DJ, Morris RG, Bird CC, Hooper ML and Wyllie $\mathrm{AH}$ (1993) Thymocyte apoptosis induced by p53-dependent and independent pathways. Nature 362: 849-852

45. Hickman ES, Moroni MC and Helin K (2002) The role of p53 and pRB in apoptosis and cancer. Curr. Opin. Genet. Dev. 12: 60-66

46. Polyak K, Xia Y, Zweier JL, Kinzler KW and Vogelstein B (1997) A model for p53-induced apoptosis. Nature 389: 300-305

47. Strocchi P, Pession A and Dozza B (2003) Up-regulation of CDK5/p35 by oxidative stress in human neuroblastoma IMR-32 cells. J. Cell. Biochem. 88: 758-765

48. Foley $P$ and Riederer $P(2000)$ Influence of neurotoxins and oxidative stress on the onset and progression of Parkinson's disease. J. Neurol. 247 (Suppl 2): II82-II94

49. Zhang W, Wang T, Qin L, Gao HM, Wilson B, Ali SF, Zhang W, Hong JS and Liu B (2004) Neuroprotective effect of dextromethorphan in the MPTP Parkinson's disease model: role of NADPH oxidase. FASEB J. 18: 589-591

50. Zhang J, Krishnamurthy PK and Johnson GV (2002) Cdk5 phosphorylates p53 and regulates its activity. J. Neurochem. 81: 307-313

51. Degterev A, Boyce M and Yuan J (2003) A decade of caspases. Oncogene 22: 8543-8567

52. Rubin $E$ and Rottenberg $H$ (1982) Ethanol-induced injury and adaptation in biological membranes. Fed. Proc. 41: 2465-2471

53. Gong J, Li X and Darzynkiewicz Z (1993) Different patterns of apoptosis of HL60 cells induced by cycloheximide and camptothecin. J. Cell. Physiol. 157: 263-270

54. Morris EJ, Keramaris E, Rideout HJ, Slack RS, Dyson NJ, Stefanis L and Park DS (2001) Cyclin-dependent kinases and P53 pathways are activated independently and mediate Bax activation in neurons after DNA damage. J. Neurosci. 21: 5017-5026

55. Cotter TG, Glynn JM, Echeverri F and Green DR (1992) The induction of apoptosis by chemotherapeutic agents occurs in all phases of the cell cycle. Anticancer Res. 12: 773-779
56. Gradzka I, Skierski J and Szumiel I (1998) DNA repair, cell cycle progression and cell death following camptothecin treatment in two murine lymphoma L5178Y sublines. Cell Biochem. Funct. 16: 239-252

57. Fang $L$, Fang $J$ and $C h e n C Q(2001)$ TNF receptor-associated factor-2 binding site is involved in TNFR75-dependent enhancement of TNFR55-induced cell death. Cell Res. 11: 217-222

58. Olney JW, Wozniak DF, Jevtovic-Todorovic V, Farber NB, Bittigau P and Ikonomidou C (2002) Drug-induced apoptotic neurodegeneration in the developing brain. Brain Pathol. 12: 488-498

59. Blom WM, de Bont HJ, Meijerman I, Mulder GJ and Nagelkerke JF (1999) Prevention of cycloheximide-induced apoptosis in hepatocytes by adenosine and by caspase inhibitors. Biochem. Pharmacol. 58: 1891-1898

60. Dalton SR, Wiegert RL, Baldwin CR, Kassel KM and Casey CA (2003) Impaired receptor-mediated endocytosis by the asialoglycoprotein receptor in ethanolfed mice: implications for studying the role of this receptor in alcoholic apoptosis. Biochem. Pharmacol. 65: 535-543

61. Wang KK (2000) Calpain and caspase: can you tell the difference? Trends Neurosci. 23: 20-26

62. Gray N, Detivaud L, Doerig C and Meijer L (1999) ATP-site directed inhibitors of cyclin-dependent kinases. Curr. Med. Chem. 6: 859-875

63. Vaghefi $H$, Hughes $A L$ and Neet KE (2004) Nerve growth factor withdrawal-mediated apoptosis in naive and differentiated PC12 cells through p53/caspase-3-dependent and -independent pathways. J. Biol. Chem. 279: 15604-15614

64. Baptiste N and Prives C (2004) p53 in the cytoplasm: a question of overkill? Cell 116: 487-489

65. Leist $M$ and Jaattela $M(2001)$ Four deaths and a funeral: from caspases to alternative mechanisms. Nat. Rev. Mol. Cell. Biol. 2: 589-598

66. Sandal T, Stapnes C, Kleivdal H, Hedin L and Doskeland SO (2002) A novel, extraneuronal role for cyclin-dependent protein kinase 5 (CDK5): modulation of cAMP-induced apoptosis in rat leukemia cells. J. Biol. Chem. 277: 2078320793

67. Rosales J, Han B and Lee KY (2003) Cdk7 functions as a cdk5 activating kinase in brain. Cell Physiol. Biochem. 13: 285-296

68. Gong X, Tang X, Wiedmann M, Wang X, Peng J, Zheng D, Blair LA, Marshall J and Mao Z (2003) Cdk5-mediated inhibition of the protective effects of transcription factor MEF2 in neurotoxicity-induced apoptosis. Neuron 38: $33-46$

69. Karasavvas N, Erukulla RK, Bittman R, Lockshin R and Zakeri Z (1996) Stereospecific induction of apoptosis in U937 cells by $\mathrm{N}$-octanoyl-sphingosine stereoisomers and $\mathrm{N}$-octyl-sphingosine. The ceramide amide group is not required for apoptosis. Eur. J. Biochem. 236: 729-737

70. Laemmli UK (1970) Cleavage of structural proteins during the assembly of the head of bacteriophage T4. Nature 227: $680-685$ 